\title{
TV Advertisement and Menstrual Hygiene Management
}

\author{
Lutfun Nahar Poly \\ Department of Sociology, University of Barishal, Barishal, Bangladesh \\ E-mail: ahmedpoly009@gmail.com
}

\begin{abstract}
Ashikuzzaman (Corresponding Author)
Lecturer, Department of Sociology, University of Barishal, Barishal, Bangladesh

E-mail: ashik.du20@gmail.com
\end{abstract}

Eashrat Jahan Eyemoon

Lecturer, Department of Sociology, University of Dhaka, Dhaka, Bangladesh

E-mail: israteyemoon@gmail.com

Received: Sep. 2, 2019 Accepted: Nov. 3, 2019 Published: Jan. 15, 2020

doi:10.5296/ijssr.v8i1.15387 URL: http://dx.doi.org/10.5296/ijssr.v8i1.15387

\begin{abstract}
Menstruation is an absolute natural-normal biological process of adolescents though it is unfortunately accompanied with different taboos in the society of Bangladesh. A significant number of adolescent girls have considerable lacuna of knowledge on menstruation as well as menstrual hygiene management. Thus, the aim of the study is to know how the issue of menstruation is presented on TV advertisement and what roles TV advertisements play in shaping the knowledge, attitude, and practice of girls and their parents on menstruation and menstruation hygiene management. Both content analysis and questionnaire survey have been used to present the realities of the role of TV advertisement in menstrual hygiene management process in Bangladesh. At present, about 70 percent girls are inspired to use sanitary napkin watching TV advertisement. TV advertisements play vital role to break the shackle of menstrual taboo and also provide essential information about menstruation as well as menstrual hygiene management.
\end{abstract}

Keywords: Adolescent Girls, Menstruation, Menstrual Hygiene Management, Menstrual Taboo, TV Advertisement 


\section{Introduction}

Menstruation is a major part of life for every woman. It is very much natural-normal biological process and experienced possibly by all adolescent girls and women (Golub, 1992; Koff, Rierdan, \& Silverstone, 1978). Influential cultural institutions like Religion, Science and Media are highly responsible in shaping and constructing the idea of menstrual process. Unawareness, miss conceptions, vague perceptions, unsafe practices during menstruation is very much common among the young women (Anjum et al., 2010 and Patil et al., 2011). For example- Anjum et al. noted that the body image of women, their perception on diseases, food habits, using medicines, use of contraceptives and the planning of pregnancies are negatively affected with their attitudes towards menstruation. Feelings of unchaste, shame and fear of menstrual blood becoming visible restricts girl's social mobility (Ali and Rizvi, 2009; Rashid, 2000; Uskul, 2004). Globally, a significant portion of female population is in their productive age. Thus, they should be in the process of menstruation and menstrual hygiene management (House, Mahon \& Cavill, 2012). Some 34 percent adolescent girls in Bangladesh knew about menstruation before they have experienced it (Rashid, 2000). Although menstruation is a normal process, people of developing countries have tendency to maintain its secrecy (Bharadwaj \& Patkar, 2004; Mahon \& Fernandes, 2010) considering it shameful and hidden (Ali and Rizvi, 2009; Rashid, 2000; Uskul, 2004) because of cultural taboos related to sexuality and reproductive health while Bangladesh is no anomaly of it. For this reason, adolescents could hardly gather proper knowledge and exact information on reproductive functions as well as reproductive health (Warenius et al., 2007; Mahon \& Fernandez, 2010).

Menstrual Hygiene Products like sanitary pads were first inaugurated in Bangladesh in the 1990s. Although there were menstrual hygiene products, the use of pieces of cloth, cotton wool, ash, husk, sand, bark, and polythene were not stopped by the adolescents (Mahon \& Fernandez, 2010). Whereas, sanitary pads were used only by 7-10 percent of female out of a total 591 million females in India (Dasgupta \& Sarkar, 2008; Mahon \& Fernandez, 2010; Sinha, 2011). But the other nations of the East are in better situation where the use of sanitary napkins in Singapore and Japan is $100 \%$. In Malaysia and China the percentage of using sanitary napkins are 88 percent and 64 percent respectively. After the World War II, women became very aware of using sanitary napkins through TV Advertisement to manage their hygiene and promoted themselves to work (Delaney et al., 1988). Egyptian adolescents get their mothers as the prime sources of information on menstruation, followed by mass media which affect their knowledge and attitude (Eswi, Helal and Elarousy 2012). The campaigns on menstrual hygiene products through TV Advertisement have actually come to the light enormously in the late $19^{\text {th }}$ century (Vostral, 2008) when women were attracted to hygiene products for menstruation. To have successful daily activities with freshness and to hide the leakages, TV advertisers always encourage menstrual hygiene products (Merskin, 1999).

Thus, at present, pad related TV advertisements play a vital role to explore the source of information regarding menstruation and help to break down the menstrual taboo and also provide reliable information about menstrual hygiene management. Pad related TV advertisements provide menstrual information among girls in managing their menstruation. 


\subsection{Scope of the Study}

Many girls are not aware of menstruation before their menarche. For the lack of access to reliable source of information regarding menstruation, girls face many health problems and adult women may hold misconceptions about the physiology of menstruation and its management. At present, pad related TV advertisement openly shows and gives information about hygiene related practices of girls during menstruation. And this study attempts to explore it. Adolescent females in colleges create their own world at their puberty having distinct attitude toward menstrual cycle. Cultural perspective, knowledge gap, embarrassment to speak out at home and outside may affect this attitude. Also, there is scattered research that examines female attitude and knowledge about menstruation among female adolescents in Bangladesh. Therefore, the current study will contribute to a better understanding of the attitude, knowledge and practice of female adolescents related to menstruation.

\subsection{Objectives of the Study}

- To know how the issue of menstruation is presented in TV advertisement.

- To know what roles TV advertisements play in shaping the knowledge, attitude and practices of adolescent girls on menstruation and menstruation hygiene management process.

\section{Research Methodology}

\subsection{Methods and Techniques of Data Collection}

Content analysis and questionnaire survey methods have been used in the study. Content analysis method has been used to scrutinize different TV advertisements to depict the way menstruation related issues presented in the TV media. To gather personal data related to age of the respondents, their age of menarche, and the knowledge of adolescent girls about menstruation, a self-administrated questionnaire is used. It has been used to depict the comprehensive situation of the knowledge, attitude and practices of menstrual hygiene management process among adolescent girls and the role of TV advertisements in influencing this process.

\subsection{Participants}

Tafajjel Hossen Manik Mia College and Barishal Women's College in Barishal, Bangladesh have been selected as study area for the resemblance of the nature of the study. Both colleges are only for girls. Probability sampling, more precisely stratified random sample has been used for selecting 90 samples from the total students of these two colleges. Female students (aged 16 to 18) are the unit of analysis to get complete picture of the study. They were in different grades, voluntarily included in the study and were confirmed that all information obtained would be kept confidential and secure. Only female students who experienced menarche were eligible as a participant.

\subsection{Tools and Ethical Considerations}

Data were coded, analyzed and processed using Statistical Package for Social Sciences 


\section{Ml Macrothink}

(SPSS). The frequency distributions of the study variables has been measured by descriptive analyses. Data from content analysis have been processed manually. In this study, the researchers tried to maintain ethical standards in every phase of the study. The researchers tried to avoid all types of biasness. Approval letter was obtained from mentioned college authorities to get access the related documents of participants. The objectives and the implications of the research were briefly clarified to the administration and the students of the colleges. The willing students who experienced menstruation gave their written consents. Confidentiality and privacy of the respondents are ensured.

\section{Results}

\subsection{Content Analysis: TV Advertisement and Menstruation Hygiene Management}

Sanitary napkin related TV advertisements generally give the message about menstrual hygiene and sometimes circulate such messages that help to break down the menstrual related taboos. The researchers have analyzed the content of sanitary napkin related TV advertisement.

The advertisement of Senora Confidence Sanitary Napkin highlights the issue of menstruation whether it is an obstacle for the study of female students or not. This Advertisement has a symbolic meaning which gives inspiration to the mothers to make their daughter confident using sanitary napkin so that they can appear at exam. Here is the pictorial discussion.

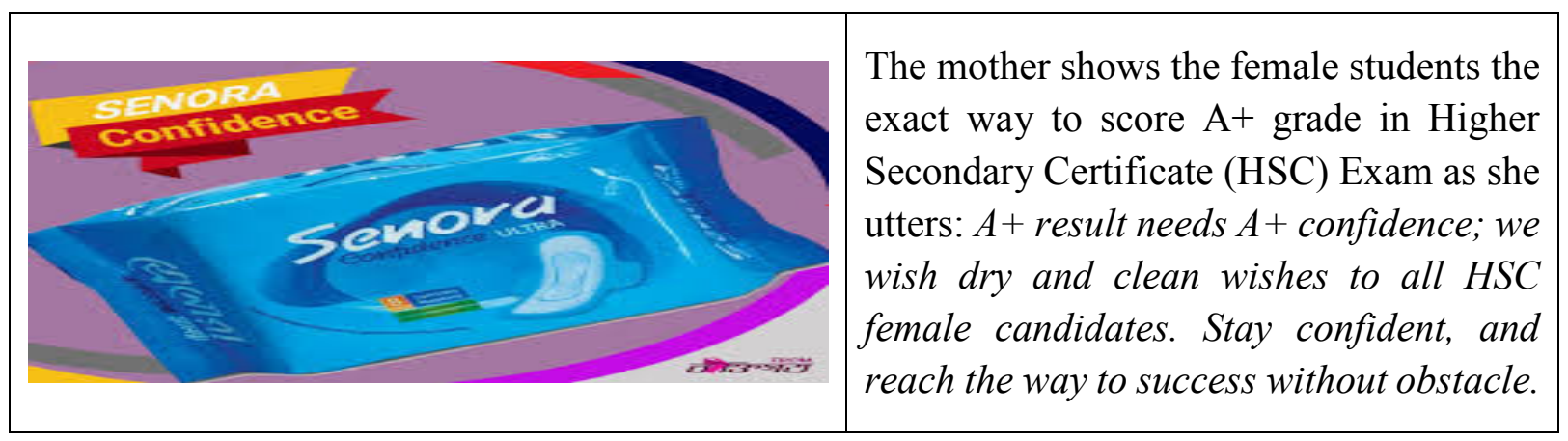

Figure 1. Senora confidence Ad

The Advertisement of Whisper Sanitary Napkin (Touch the Pickle) has brought the issue of prejudice and taboo related to menstruation to the audiences. This advertisement is a great initiative in itself which pronounces that girls and their guardians should get themselves rid from all sets of taboos associated with menstruation to reach their fullest potential. They are free to do anything anywhere while they have menstruation. Here is the pictorial discussion. 


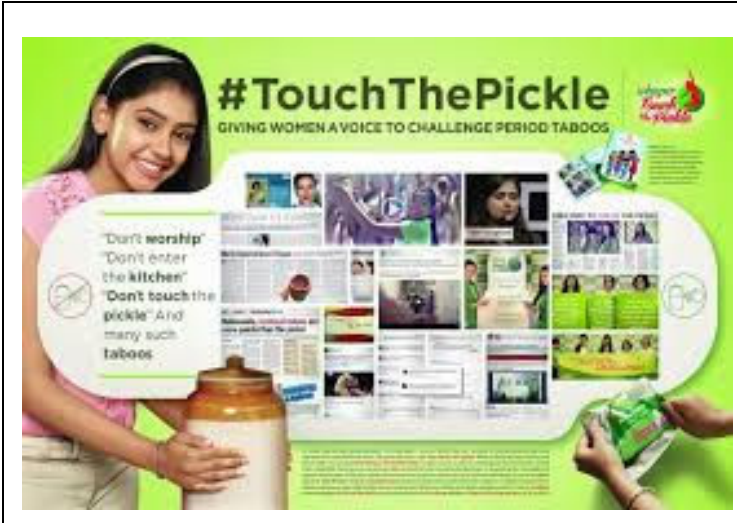

Grandmother advises the girl that reserved food like pickle or Kashandi should not be touched during menstruation, moreover, running and jumping are strictly prohibited. But in the last portion of this Advertisement, we see the girl touches the pickle and play Badminton freely.

Figure 2. Whisper sanitary napkin Ad

The Advertisement of Savlon Freedom Sanitary Napkin was launched with the Slogan "MUKTO BIHONGGO". The message of this Advertisement is that sanitary napkin enhances girls' confidence and freedom in moving everywhere without any obstacle. It has inspired them to stay in hygiene to make a better change in life. Here is the pictorial discussion.

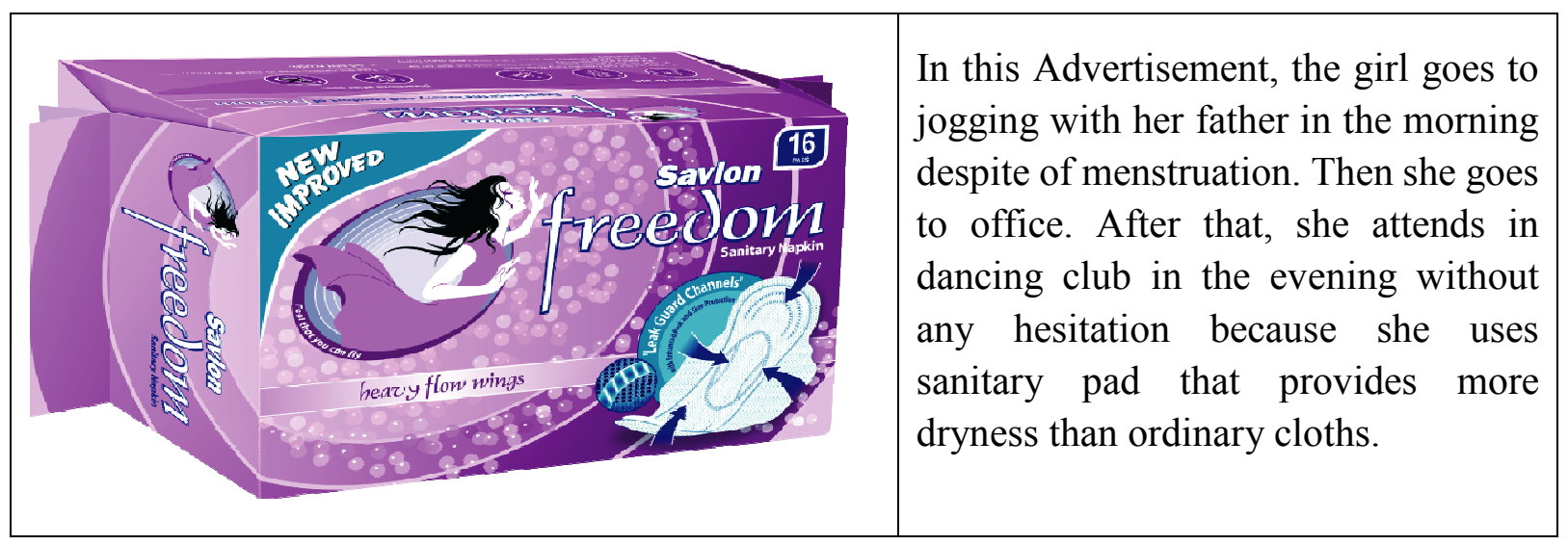

Figure 3. Savlon freedom sanitary napkin Ad

The Advertisement of Tulip napkin highlights the removal of anxiety of girls on the issue of menstruation. The explanation for the reason behind their smile is the happiness of maintaining menstrual hygiene. Actually a girl can behave herself in her natural way when she takes the menstruation process as a natural one and she can keep the privacy without hesitation of licking by using sanitary napkin. In addition, the image of smiling friends indicates their intimate friendship as well as the initial letter ' $\mathrm{T}$ ' of Tulip in the largest font written in the shape of a woman creates an impression of female freedom and bonding. Such bonding reflects the changes of socio-cultural perception on menstruation. Here is the pictorial discussion. 


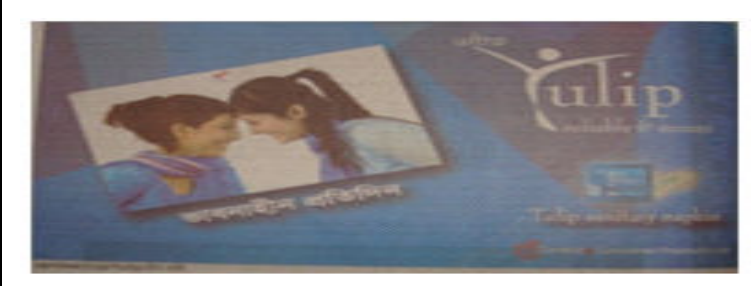

The Advertisement presents two (early adolescent) friends in a close up camera shot. The two friends smile at each other and the text just beneath the image reads "Every day without tension".

Figure 4. Tulip sanitary napkin Ad

In Senora Advertisement, a doctor explains the suitability of using Senora sanitary napkin. This Advertisement gives helpline for the query on menstruation and provides some important medical suggestions. The doctor strongly forbids using old clothes by explaining its demerits. The viewers get strong information from a specialist to manage menstrual hygiene. Here is the pictorial discussion.
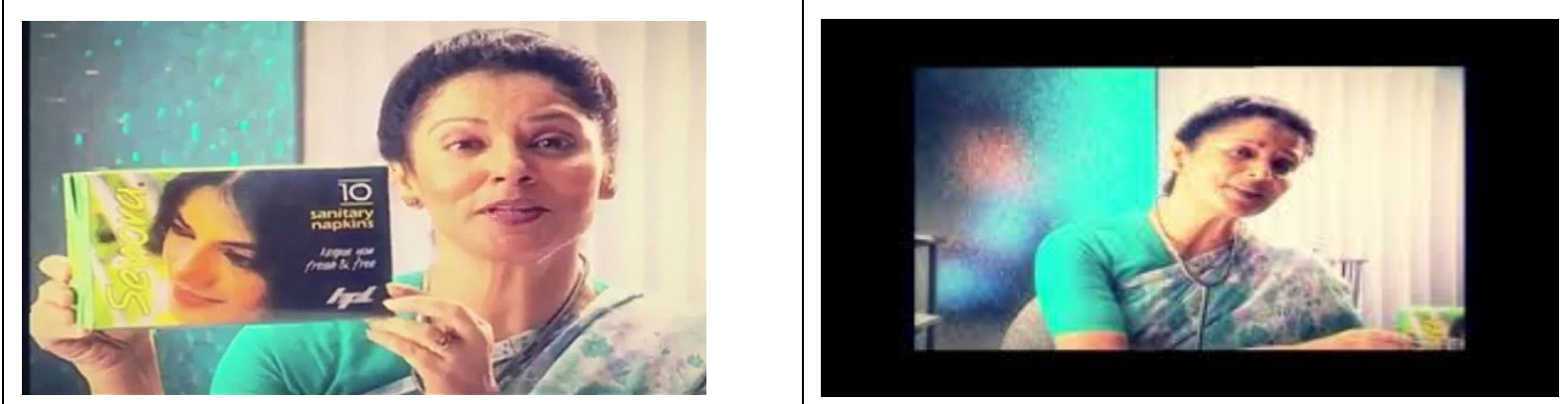

The doctor says that most of the women still follow the traditional process to use ordinary cloth that creates dangerous disease such as "Reproductive Tract Infection" or "Uterine cancer" in most of the cases. So, the medical science suggests using sanitary pad. And doctor argues that pad should be changed time to time. And this advertisement ends with a message to communicate with free medical consultation care zone- 09612222333 or 08000888000.

Figure 5. Senora sanitary napkin Ad.

Whisper sanitary napkin Advertisement represents the way a girl becomes confident enough to break confidentiality. Generally people treat that menstruation is a private thing and it should be kept confidential. This Advertisement shows the bravery of girls in breaking the taboos. It is a sign of independence and breaking shackle of girls. They dare to come out of their cocoons. 


\section{Ml Macrothink}

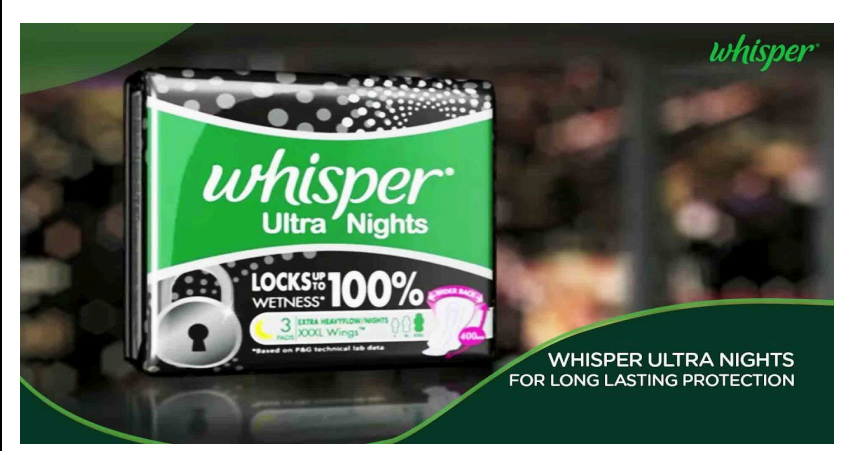

A girl goes to jogging in the morning and everyone becomes astonished to see the logo of her dress entitled "I am menstruating”.

Figure 6. Whisper sanitary napkin Ad.

Joya Sanitary Napkin Advertisement shows the success of girls and suggests the necessity of taking nutritious foods for girls. Joya sanitary napkin advertisement shows once a girl was riding cycle, playing cricket and doing other activities. After a while, she starts to feel something is going wrong with her and that is menstruation. Then she goes back to home and starts to cry loudly closing the door and utters 'I won't go to school'.

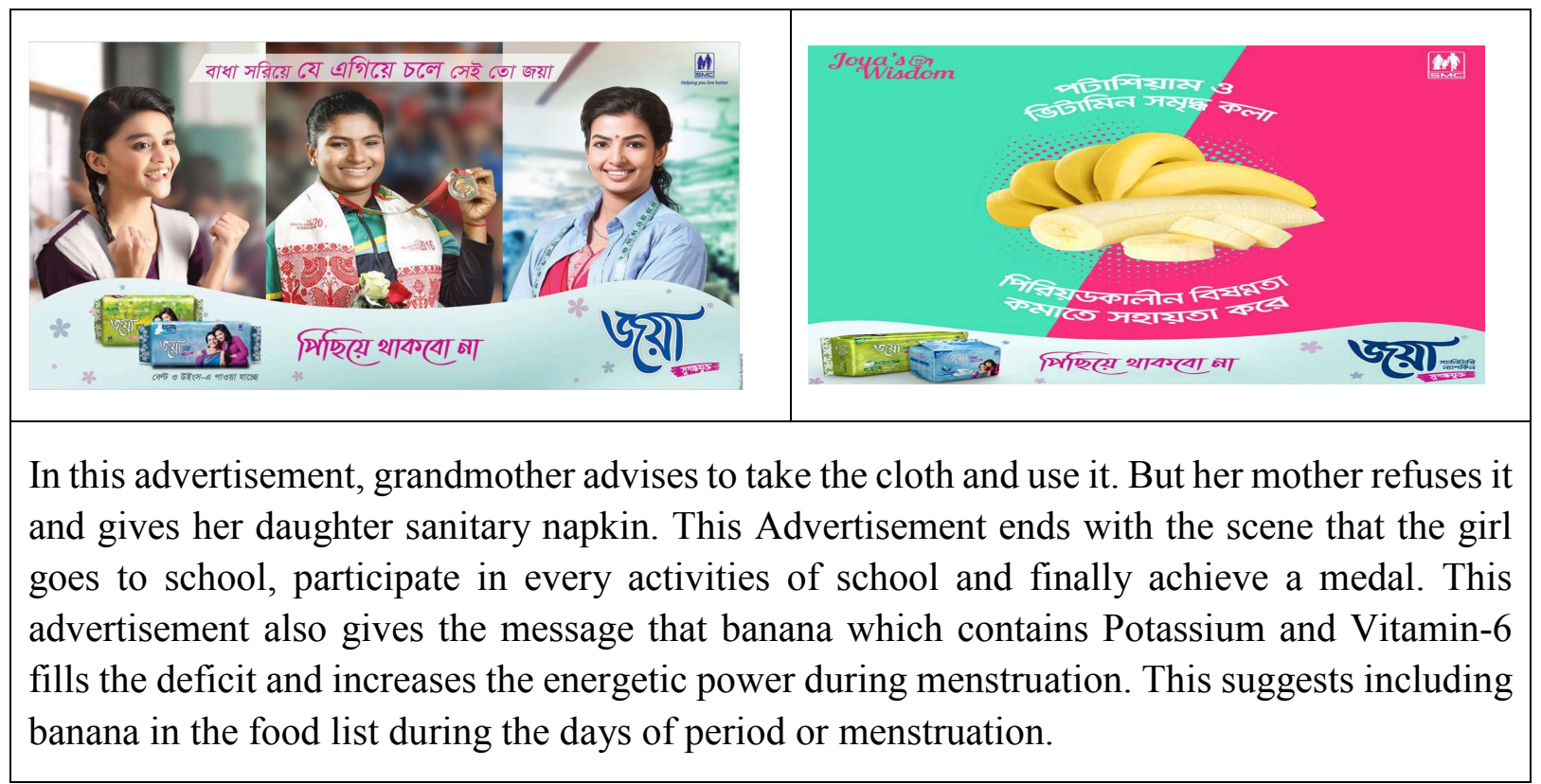

Figure 7. Joya sanitary napkin Ad.

3.2 Quantitative Data Analysis: TV Advertisements and the Knowledge, Attitude and Practices of Adolescent Girls on Menstruation and Menstruation Hygiene Management

All of the respondents are experiencing the age of their journey as capable of having menstruation. Their ages vary from 16 to 18 (Table 1 ). 


\section{Al Macrothink}

International Journal of Social Science Research

ISSN 2327-5510 2020, Vol. 8, No. 1

Table 1. Age of the respondents

\begin{tabular}{lll}
\hline Age & Frequency & Percent \\
\hline 16 & 33 & 36.7 \\
17 & 41 & 45.6 \\
18 & 16 & 17.8 \\
\hline
\end{tabular}

Source: Field data 2017

This table 1 shows 36.7 percent, 45.6 percent and 17.8 percent girls are at the age of 16,17 and 18 respectively proving that they are at the age of puberty.

Table 2. Age at first menstruation

\begin{tabular}{lll}
\hline Age at first menstruation & Frequency & Percent \\
\hline 11 & 9 & 10.0 \\
12 & 19 & 21.1 \\
13 & 38 & 42.2 \\
14 & 19 & 21.1 \\
15 & 5 & 5.6 \\
\hline
\end{tabular}

Source: Field data 2017

The table 2 shows that the highest frequency of having menstruation of the girls is at the age of 13 which is 42.2 percent while the lowest frequency is 5.6 percent.

Table 3. Reaction during first menstrual time

\begin{tabular}{lll}
\hline Criteria & Frequency & Percent \\
\hline Fear & 50 & 55.6 \\
Shame & 9 & 10.0 \\
Surprise & 20 & 22.2 \\
Sadness & 4 & 4.4 \\
Others & 7 & 7.8 \\
\hline
\end{tabular}

Source: Field data 2017

This table 3 shows that 55.6 percent girls react to fear during first menstrual time and while only 4.4 percent become sad during first menstrual time. 


\section{Macrothink}

Table 4. First sharing about menstruation

\begin{tabular}{lll}
\hline First sharing about menstruation & Frequency & Percent \\
\hline Mother & 67 & 74.4 \\
Sister & 16 & 17.8 \\
Grandmother & 2 & 2.2 \\
Friends & 5 & 5.6 \\
\hline
\end{tabular}

Source: Field data 2017

The table 4 shows that 74.4 percent girls first share her menstruation with mother. Only 2.2 percent first share her menstruation with Grandmother.

Table 5. Watching TV advertisement on use of sanitary napkin

\begin{tabular}{lll}
\hline Criteria & Frequency & Percentage \\
\hline Yes & 62 & 68.9 \\
No & 28 & 31.1 \\
\hline
\end{tabular}

Source: Field data 2017

This table 5 shows that 68.9 percent girls are inspired to use sanitary pad by watching pad related TV advertisement and the rest got other sources to be inspired.

Table 6. Gathering knowledge about MH through watching TV advertisement

\begin{tabular}{lll}
\hline Criteria & Frequency & Percent \\
\hline Accurate knowledge about menstruation & 15 & 16.7 \\
Reproductive tract infection for using ordinary cloth & 12 & 13.3 \\
To keep dry & 8 & 8.9 \\
Above all & 55 & 61.1 \\
\hline
\end{tabular}

Source: Field data 2017

This table 6 shows that 61.1 percent girls get accurate knowledge about menstruation, awareness on reproductive tract infection for using ordinary cloth and knowledge on keeping themselves dry through watching TV advertisement. 


\section{Macrothink \\ International Journal of Social Science Research \\ ISSN 2327-5510 \\ 2020, Vol. 8, No. 1}

Table 7. Following the promotional knowledge of TV advertisement

\begin{tabular}{lll}
\hline Criteria & Frequency & Percent \\
\hline Discussing secret issue & 20 & 22.2 \\
Going to college or outside during menstruation & 3 & 3.3 \\
Withdrawing all menstrual taboo & 4 & 4.4 \\
Having free suggestion of doctors & 13 & 14.4 \\
Above all & 44 & 48.9 \\
No comment & 6 & 6.7 \\
\hline
\end{tabular}

Source: Field data 2017

The table 7 shows that 48.9 percent respondents gathered knowledge about discussing secret issue, going to college or outside during menstruation, withdrawing all menstrual taboo, having free suggestion of doctors while 22.2 percent respondents gather knowledge about discussing secret issue through watching pad related TV advertisement. Only 14.4 percent respondents gather knowledge about having free suggestion of doctors.

Table 8. Awareness of using of MH materials through TV advertisement

\begin{tabular}{lll}
\hline Criteria & Frequency & Percent \\
\hline Use hygienic sanitary pad & 69 & 76.6 \\
Not to use old cloth and other things & 21 & 23.3 \\
Doctor's suggestion & 2 & 2.2 \\
\hline
\end{tabular}

Source: Field data 2017

This table 8 shows that 76.6 percent girls directly use hygienic sanitary pad while 23.3 percent girls are inspired to maintain menstrual hygiene and they do not use cloth after seeing pad related TV ad.

Table 9. Pad related TV Advertisement and feeling of hesitation

\begin{tabular}{lll}
\hline Criteria & Frequency & Percent \\
\hline Yes & 50 & 55.6 \\
No & 40 & 44.4 \\
\hline
\end{tabular}

Source: Field data 2017

This table 9 shows that 55.6 percent girls hesitate to see pad related TV advertisement with male member of family. 


\section{Macrothink \\ International Journal of Social Science Research \\ ISSN 2327-5510 2020, Vol. 8, No. 1}

Table 10. Medium of changing the respondents' attitude

\begin{tabular}{lll}
\hline Criteria & Frequency & Percentage \\
\hline Watching TV advertisement & 38 & 42.2 \\
Discussing with friends & 7 & 7.8 \\
Discussing with mother & 37 & 41.1 \\
Reading the textbook & 8 & 8.9 \\
\hline
\end{tabular}

Source: Field data 2017

This table 10 shows that 42.2 percent girls have changed their attitude from the first experience through watching TV advertisement while 41.1 percent girls get their chance to change their attitude from through discussing with mother. About nine percent girls change their attitude from through reading the textbook.

Table 11. The extent of attitude change through pad related TV advertisement

\begin{tabular}{lll}
\hline Criteria & Frequency & Percent \\
\hline Breaking shame & 10 & 11.1 \\
Being more conscious about hygiene & 32 & 35.6 \\
Breaking the shackle of dependency & 5 & 5.6 \\
Being tension-free & 6 & 6.7 \\
Above all & 34 & 37.8 \\
Others & 2 & 2.2 \\
No comment & 1 & 1.1 \\
\hline
\end{tabular}

Source: Field data 2017

This table 11 shows that 35.6 percent girls have conscious about menstrual hygiene while 37.8 percent could make a change like breaking shame, being more conscious about hygiene, being tension-free through watching pad related TV advertisement. Some 6.7 percent girl could break the shackle of dependency through watching pad related TV advertisement.

Table 12. Following motivational messages about MHM in TV advertisement

\begin{tabular}{lll}
\hline Criteria & Frequency & Percent \\
\hline Yes & 86 & 95.6 \\
No & 4 & 4.4 \\
\hline
\end{tabular}

Source: Field data 2017

This table 12 shows that $95.6 \%$ girls had psychological suggestion about MHM in TV advertisement. 
Table 13. Prohibition to go to college and restriction from family to do outside work during menstruation

\begin{tabular}{|c|c|c|c|c|}
\hline \multirow{2}{*}{ Criteria } & \multicolumn{2}{|c|}{ Prohibition to go to college } & \multicolumn{2}{|c|}{ Restriction from family to do outside work } \\
\hline & Frequency & Percent & Frequency & Percent \\
\hline Yes & 55 & 61.1 & 23 & 25.6 \\
\hline No & 35 & 38.9 & 67 & 74.4 \\
\hline
\end{tabular}

Source: Field data 2017

This table 13 shows that 61.1 percent girls say that their family prohibits them going to college and this is very significant while 25.6 percent girls are restricted to do outside work.

Table 14. Other Restrictions during menstruation

\begin{tabular}{lll}
\hline Criteria & Frequency & Percent \\
\hline Wearing particular dress & 1 & 1.1 \\
Moving freely in any place anytime & 9 & 10.0 \\
Eating particular food & 6 & 6.7 \\
Not at all & 74 & 82.2 \\
\hline
\end{tabular}

Source: Field data 2017

The table 14 shows girls have some restrictions to wear particular dress, move freely or eat particular dress during menstrual time.

\section{Discussion}

Results show that 42.2 percent of the respondents experienced menarche at the age of 13 and more than half of then was afraid of the situation while 20 percent were surprised. They informed their mother at the first (74.4 percent), followed by sisters (17.8 percent) and friends (5.6 percent). TV advertisement is the prime source of knowledge and information for 42.2 percent followed by mother (41.1 percent).Sanitary pad is the good protection to do daily activities rather than ordinary cloths and female child are not retired to study or workplace because pad provides hygienic antibacterial that effectively improves incretion, strengthening immunity, reducing stress, eliminating vaginal infection, bacteria and gives comfort during menstrual period.

Pad related TV advertisements usually provide information about awareness, knowledge and hygiene about menstruation. They play vital roles to change the attitude towards menstrual taboo. People easily capture the message and is affected by Pad related TV advertisement to break the menstrual taboo and be more conscious about hygiene.

Girls would not discuss about menstruation with their parents earlier in Bangladesh. But this situation is changing because there are TV advertisements about menstruation and those give the information of being no shamefulness and the urgency of awareness about menstrual issue. 
At present, about 70 percent girls learn through watching pad related TV advertisement. So, TV advertisements are highly influential for the menstrual activities of girls.

It is surprising that most girls think sanitary pad is good protection for doing their day-to-day activities because sanitary pad is more hygiene and user friendly and also easy to dump it. As a result, girls can play, study and do daily activities.

Pad related TV advertisements give information about menstrual hygiene management. Most of the respondents are inspired to obey the hygiene issue after watching pad related TV advertisements. About 62 percent girls learn many things from TV advertisement such as accurate knowledge about menstruation, reproductive tract infection or possible to be uterine cancer because of using old cloth.

TV advertisement always ends up with menstrual hygiene related psychological suggestion and about 96 percent girls are motivated with this. Actually, pad related TV advertisements change the attitude of girls because about 45 percent of the respondents cited that they watch these with male members in their family and do not feel any hesitation. These findings prove that girls are changing their attitude through TV advertisements because media constituently influences on adolescent child through their programs.

Girls have come to know from TV advertisements that all activities such as play the sports, go to college, go to outside in any place in any time are possible to accomplish even they are menstruating. But they hardly consult a doctor if they feel sick during menstruation.

\section{Conclusion and Recommendations}

Pad related TV advertisement and girls' mother provide the proper menstrual management knowledge for girls. The advertisements also enormously influence the menstrual activities with the potentiality to contribute a lot on the issue of breaking the menstrual taboo and providing menstrual hygiene related psychological suggestions.

Based on the study findings, the following were recommended:

- Proper knowledge on physical and psychological aspects of menstruation and puberty hygiene should be provided to the adolescents before the onset of their menarche.

- All stakeholders, i.e. parents, teachers, children, government and the community should cooperate to generate solutions for creating safe menstrual care to bestow a better and dignified future for our adolescent girls.

- As most of the respondents are aware about menstruation by TV advertisement, the authority of the media advertiser should give more focus on building up the hygiene and health conscious related advertisement.

- Religious as well as civic leaders and parents should come forward to discuss about menstruation openly.

- The Ministry of Education should include menstrual hygiene management related comprehensive school health education and awareness programs on menstrual physiology 
in the curriculum of primary, secondary and higher secondary levels.

- Last but not the least; further studies should be conducted in the area of reproductive health and menstrual hygiene among girls for the betterment of maternal health.

\section{Acknowledgement}

The authors would like to give appreciation to the students who participated in the study.

\section{References}

Ali, T. S., \& Rizvi, S. N. (2010). Menstrual knowledge and practices of female adolescents in urban Karachi, Pakistan. Journal of Adolescence, 33(4), 531-541. https://doi.org/10.1016/j.adolescence.2009.05.013

Anjum, F., Zehra, N., Haider, G., Rani, S., Siddique, A. A., \& Munir, A. A. (2010). Attitude towards Menstruation among Young Women. PakJ Med Sci, 26(3), 619-622.

Bharadwaj, S., \& Patkar, A. (2004). Menstrual Hygiene and Management in Developing Countries: Taking Stock, Mumbai. Junction Social. Retrieved January 19, 2013, from http://www.mum.org/menhydev.htm

Dasgupta, A., \& Sarkar, M. (2008). Menstrual Hygiene: How Hygienic is the Adolescent Girl? Indian Journal of Community Medicine, 33(2), 77-80. https://doi.org/10.4103/0970-0218.40872

Delaney, J., Lupton, M. J., \& Toth, E. (1988). The curse: A cultural history of menstruation (2nd ed.). Chicago: University of Illinois Press

Eswi, A., Helal, H., \& Elarousy, W. (2012) Menstrual Attitude and Knowledge among Egyptian Female Adolescents. Journal of American Science, 8(6), 555-565. Retrieved from htttp://www.americanscience.org.71

Fernandes, M. (2008). The Untold Story - Menstrual Hygiene: Issues of Awareness and Practices. Paper presented at the 3rd South Asian Conference on Sanitation, Delhi, India, 19-21 [Online]. Retrieved from http://www.menstrualsanitation.org/publications/PartIII.pdf

Golub, S. (1992). Periods: From menarche to menopause. Newbury Park, CA: Sage.

House, S., Mahon, T., \& Cavill, S. (2012). Menstrual Hygiene Matters: A Resource for Improving Menstrual Hygiene around the World. Retrieved from http://www.wateraid.org/mhm

Koff, E., Rierdan, J., \& Silverstone, E. (1978). Changes on representation of body image as a function of menarcheal status. Developmental Psychology, 14, 635-642. https://doi.org/10.1037/0012-1649.14.6.635

Mahon, T., \& Fernandes, M. (2010). Menstrual Hygiene in South Asia. A Neglected Issue for WASH (water, sanitation and hygiene) Programmes. Gender \& Development, 18(1), 99-113. https://doi.org/10.1080/13552071003600083 


\section{Macrothink}

International Journal of Social Science Research

ISSN 2327-5510 2020, Vol. 8, No. 1

Merskin, D. (1999). Adolescence, advertising, and the idea of menstruation. Sex Roles, 40, 941-957. https://doi.org/10.1023/A:1018881206965

Patil, R., Agarwal, L., Khan, M. I., Gupta, S. K., Vedapriya, D. R., Raghavia, M., \& Mittal, A. (2011). Beliefs about menstruation: a study from rural Pondicherry. Indian Journal of Medical Specialities, 2(1), 1. https://doi.org/10.7713/ijms.2011.0006

Rashid, S. F. (2000). Providing Sex Education to Adolescents in Rural Bangladesh: Experiences from BRAC. Gen \& Dev. Jul, 8(2), 28-37. https://doi.org/10.1080/741923625

Singh, A. J. (2006). The place of menstruation in the reproductive lives of women of rural north India. Indian Journal of Community Medicine, 31(1), 10-14. https://doi.org/10.4103/0970-0218.54923

Uskul, A. K. (2004). Women's menarche stories from a multicultural sample. Social Science and Medicine, 59(4), 667-679. https://doi.org/10.1016/j.socscimed.2003.11.031

Vostral, S. L. (2008). Under Wraps: A History of Menstrual Hygiene Technology, Rowman and Littlefield Publishers, Inc, Lanham, Maryland. Women's Studies, 40(2), 229-221, https://doi.org/10.1080/00497878.2011.537993

Warenius, L., Pettersson, K. O., Nissen, E., Hojer, B., Chishima, P., \& Faxelid, E. (2007). Vulnerability and Sexual and Reproductive Health among Zambian Secondary School Students. Culture, Health \& Sexuality: International Journal for Research, Intervention and Care, 9(5), 533-544. https://doi.org/10.1080/13691050601106679

\section{Copyrights}

Copyright for this article is retained by the author(s), with first publication rights granted to the journal.

This is an open-access article distributed under the terms and conditions of the Creative Commons Attribution license (http://creativecommons.org/licenses/by/4.0/). 